\title{
Amaranth Grain Brings Health Benefits to Young Normolipidemic Rats
}

\author{
Cinthia Baú Betim Cazarin ${ }^{1, *}$, Yoon Kil Chang², Matheus Depieri' ${ }^{2}$ Everardo Magalhães Carneiro ${ }^{3}$, \\ Aparecida Sônia de Souza ${ }^{4}$, Jaime Amaya-Farfan ${ }^{1}$ \\ ${ }^{1}$ Department of Food and Nutrition, School of Food Engineering, University of Campinas, Campinas, 13083-862, Brazil \\ ${ }^{2}$ Department of Food Technology, School of Food Engineering, University of Campinas, Campinas, 13083-862, Brazil \\ ${ }^{3}$ Department of Anatomy, Cell and Molecular Biology, Institute of Biology, University of Campinas, Campinas, 13083-865, Brazil \\ ${ }^{4}$ Institute of Food Technology, ITAL, Campinas, 13070-178, Brazil
}

\begin{abstract}
This paper reports the impact of an extruded amaranth (Amaranthus spp) supplement on intestinal bile and fatty acids of normolipidemic rats. Forty-eight rats were fed either a control diet AIN 93-G (12 or 18\% protein), or one of two levels of supplemental extruded amaranth flour for 48 days. Plasma glucose, insulin, total cholesterol, their fractions, and triacylglycerols, liver weight and lipid content, cecum short-chain fatty acids and fecal excretion of bile acids were determined. While no significant differences in the levels of plasma triacylglycerols, glucose or insulin, and liver parameters due to the diet were detected. Although amaranth promotes reduction of both total and LDL serum cholesterol, increased production of butyric acid in cecum and fecal excretion of deoxycholic acid in the feces. These results suggest that amaranth used routinely as a supplement to the standard casein diet could have a health-promoting value in the normal rat.
\end{abstract}

Keywords Amaranthus cruentus, Dietary Fiber, Dyslipidemia, Cholesterol, Secondary Bile Acids, Short-Chain Fatty Acids

\section{Introduction}

Health studies reveal that metabolic disorders continue to increase in human populations world-wide. In the search for healthier foods and life styles, less common foods have received special attention and, among them, amaranth grain has a number of unique nutritional features to offer.

Amaranth grain is a pseudo-cereal crop known in the Americas for such agronomic characteristics as resistance to drought and abrupt temperature changes, as well as tolerance to salt and $\mathrm{pH}$ variations in the soil. For centuries it has been a staple food to those in Inca, Maya and Aztec civilizations, but in more recent times, its unusual compositional characteristics have promoted a number of researchers to further explore its health properties[1].

The grain's protein content may reach $15 \%$ and the balance between lysine and the sulfur amino acids approaches that of a mixture of rice and beans[2-3]. Its lipid fraction (6 to $10 \%$ ) has a high content of unsaturated fatty acids (76\%), principally linoleic acid and includes considerable amounts of squalene. Additionally, between 56 and $78 \%$ of the dry matter is starch, and from 9 to $16 \%$ is

* Corresponding author:

cinthiabetim@gmail.com (Cinthia Baú Betim Cazarin)

Published online at http://journal.sapub.org/fph

Copyright (C) 2012 Scientific \& Academic Publishing. All Rights Reserved dietary fiber[4-5].

Several studies have shown that consumption of both amaranth lipids and protein can lower the serum levels of cholesterol fractions (VLDL-cholesterol and LDLcholesterol), as well as triacylglycerol in experimental animal species, such as hamsters, rats and chickens that were raised on hypercholesterolemic diets[6-10]. Similar effects were reported in hamsters fed the whole flour[8], or in rabbits fed the extruded whole flour[11]. To our knowledge, however, no study has examined the impact of routine supplementation of amaranth flour, or its products, on the profile of fatty and bile acids in the gut of normal animals.

Considering that previous works have evaluated the cholesterol-lowering effect of amaranth in animals consuming cholesterolemic diets[9-12], and in some cases, the protein and/or lipid substitution were not clearly stated $[8,13-14]$, the objective of the present work was to assess if prolonged supplementation with extruded whole amaranth grain can offer any health value to the normal rat. Therefore, this paper will examine the alterations occurring in the lipid profile of normolipidemic rats fed a normolipidemic diet, in addition to other lipidemic parameters and its impact on the intestinal bile acid profile.

\section{Materials and Methods}




\subsection{Materials}

The amaranth (Amaranthus cruentus, cv. BRS-Alegria, a Brazil adapted grain amaranth cultivar) grains were obtained from Embrapa Cerrados (Centro de Pesquisa Agropecuária dos Cerrados, Planaltina, GO, Brazil) and the flour was produced by grinding in a hammer Mill (Marconi MA580, Piracicaba, SP, Brazil) to pass a 20 mesh screen, and later extruded in a laboratory scale Brabender single-screw extruder (model GNF 1014/2, Duisburg, Germany). The extruder settings were: $18 \%$ moisture, $3: 1$ compression rate, and temperatures of $60-65,125$ and $150^{\circ} \mathrm{C}$, for the $1 \mathrm{st}, 2 \mathrm{nd}$ and 3 rd zones, respectively. After extrusion, the dry material was submitted to grinding (20 mesh) and storage in double, thick polyethylene bags, at $4^{\circ} \mathrm{C}$.

\subsection{Animals and Diets}

The experimental protocol was authorized by the Ethics Committee of the University of Campinas (1171-2/2007), which follows the norms of the Brazilian College of Animal Experimentation (COBEA). Forty-eight 21-day old male Wistar rats (CEMIB, University of Campinas) were randomly divided into four groups and housed in individual stainless steel cages and under acclimatized conditions $\left(22^{\circ}\right.$, 12-hr light-dark cycles, $60 \%$ relative humidity), with food and water constantly available.

Whole amaranth grain was ground and extruded before they were added to the diet. Extrusion is a thermoplastic process of cooking flours in which a combination of a limited amount of moisture and mechanical work produces high attrition, resulting in the evolution of heat, gelatinization of the starches and denaturation of the proteins.

Four diets (two containing only casein, and two casein plus amaranth) were prepared according to the American Institute of Nutrition (AIN 93-G)[15], modified to supply either 12 or $18 \%$ protein in each case, by manipulation of the corn starch content, and substituting the amaranth flour for part of the standard casein, so as to provide $35 \%$ of the final protein content as amaranth protein. The lipid and carbohydrate contents of the modified diets were adjusted accordingly. The diets were made to be isoproteic and isoenergetic at each protein level, and were fed ad libitum for 48 consecutive days. Food intake was obtained by weighing the bowls daily and the mass gain by weighing the animals twice weekly.

Feces were collected daily throughout the assay and stored in a freezer for analysis. At 21 days, half (six) of the animals of every group were submitted to 12-hour of fasting, anesthetized with ketamine ( $80 \mathrm{mg} / \mathrm{kg}$ of body weight) and xylazine hydrochloride ( $8 \mathrm{mg} / \mathrm{kg}$ of body weight) for blood collection by heart puncture and organ excision. The remaining animals continued to receive the diets to the end of the assay, when they were submitted to the same procedure of the first half. Liver and cecum were removed from each animal, washed in saline and wiped in gauze prior to weighing. The cecum was frozen together with its contents in liquid nitrogen and stored at $-20^{\circ} \mathrm{C}$ for the analysis of short-chain fatty acids.

Blood samples were collected in Vacuettes ${ }^{\circledR}$ containing EDTA and kept in ice until centrifugation (1000g, $15 \mathrm{~min}$ ) in order to obtain the plasma, which was immediately stored in criotubes at $-20^{\circ} \mathrm{C}$ topped with nitrogen gas.

\subsection{Blood analysis}

Plasma lipids were determined by the enzymatic-colorimetric method[16-17] for triacylglycerols by a commercial kit (Laborlab 02700, São Paulo, Brazil). Total and HDL-cholesterol were quantified by the use of diagnostic kits Bioclin K053 and K015 (Santa Branca, Brazil), and the LDL and VLDL-cholesterols estimated using the empirical equation of Friedewald[18]. Serum glucose determination was accomplished by the glucose oxidase-peroxidase method, and insulin by radioimmunoassay[19]. Total serum proteins and albumin were quantified by colorimetric assay, using the biuret and bromcresol-green reactions, respectively (Laborlab 03800, Campinas, Brazil).

\subsection{Liver and Fecal Analyses}

Total liver cholesterol was determined following the chromatographic procedure[20]. The method of Bligh and Dyer (1959) was followed for extraction and quantification of the total lipids from the liver and feces. The short-chain fatty acid composition was determined by liquid chromatography[21-22] was employed (Prominenece Shimadzu Co. liquid chromatography, Kyoto, Japan, equipped with a DAD SPD-M20A, and a Luna $5 \mu \mathrm{m}, \mathrm{C}-18$ $100 \AA, 250 \times 4.6 \mathrm{~mm}$, column). Bile acids were quantified in the fecal material by gas chromatography (ACME, model 6100 , equipped with FID), using both He and N2 as carrier gases[23-25].

\subsection{Statistical Analysis}

The data were tabulated as means \pm SEM and analyzed using monovariate ANOVA from the SAS program, version 6 , followed by the discriminatory Tukey test, with $p \leq 0.05$ as the criterion for significance.

\section{Results}

In general, partial substitution of the standard protein casein by the extruded amaranth, whether at the 12 or at the $18 \%$ protein level, resulted in no significant changes of either body mass or diet consumption (Table 1), thus attesting to the general adequacy of the standard diet supplemented with the extruded flour of whole amaranth.

\subsection{The Blood and Liver Cholesterol and Lipids}

Consumption of a normolipidemic diet by normolipidemic rats began to show a significant decrease of about $50 \%$ in the levels of total serum cholesterol at 20 days of feeding, an effect that was maintained throughout the entire experiment 
(Table 2) and was evident at both the 12 and $18 \%$ protein levels. It was interesting to note, however, that the reduction in total cholesterol was due almost exclusively to the lowering of LDL cholesterol, without affecting the HDL-cholesterol fraction. In spite of the reduction of the serum cholesterol, no alteration was observed in the total hepatic cholesterol content, consistent with the other blood parameters, glucose, insulin and total serum protein and albumin, as shown in Table 2.

Additionally, the normal blood triacylglyerol levels were not affected by the dietary interventions, and also no effects in terms of total lipids were observed in the livers as a result of either the level of protein or the inclusion of amaranth in the diets.

Table 1. Mean $( \pm \mathrm{SE})$ of individual body masses at beginning and end of the 48-day assay, and mean daily food intakes ${ }^{1}$

\begin{tabular}{|c|c|c|c|c|}
\hline \multirow{2}{*}{ Parameter (g) } & \multicolumn{4}{|c|}{ Groups } \\
\cline { 2 - 5 } & AIN 12 & AM 12 & AIN 18 & AM 18 \\
\hline Initial mass & $54.8 \pm 4.4^{\mathrm{a}}$ & $56.3 \pm 6.4^{\mathrm{a}}$ & $56.1 \pm 5.0^{\mathrm{a}}$ & $54.9 \pm 6.1^{\mathrm{a}}$ \\
\hline Final mass & $302.0 \pm 1.5^{\mathrm{a}}$ & $332.6 \pm 8.0^{\mathrm{a}}$ & $299.2 \pm 15.9^{\mathrm{a}}$ & $320.7 \pm 35.8^{\mathrm{a}}$ \\
\hline Daily intake $^{1}$ & $18.1 \pm 0.94^{\mathrm{a}}$ & $17.4 \pm 1.48^{\mathrm{a}}$ & $19.7 \pm 0.48^{\mathrm{a}}$ & $19.0 \pm 2.48^{\mathrm{a}}$ \\
\hline
\end{tabular}

${ }^{1}$ Daily diet consumption averaged between day 30 and 48 . Values are expressed as mean $( \pm$ SD) for six rats. Rows bearing the same letter showed no significant difference between means

Table 2. Liver and serum parameters after consuming the diets for 48 days

\begin{tabular}{ccccc}
\hline & & \multicolumn{2}{c}{ Groups } \\
& AIN 12 & AM 12 & AIN 18 & AM 18 \\
\hline Liver & & & & \\
TL* & $18.0 \pm 1.8^{\mathrm{a}}$ & $15.2 \pm 1.7^{\mathrm{a}}$ & $17.8 \pm 2.9^{\mathrm{a}}$ & $15.7 \pm 2.7^{\mathrm{a}}$ \\
TCH** & $4.3 \pm 0.1^{\mathrm{a}}$ & $5.8 \pm 0.1^{\mathrm{a}}$ & $3.4 \pm 0.0^{\mathrm{a}}$ & $3.9 \pm 0.1^{\mathrm{a}}$ \\
Blood & & & \\
TG** & $42.0 \pm 28.8^{\mathrm{a}}$ & $74.9 \pm 18.4^{\mathrm{a}}$ & $77.8 \pm 30.4^{\mathrm{a}}$ & $77.4 \pm 2.3^{\mathrm{a}}$ \\
TCH\# & $0.10 \pm 0.03^{\mathrm{b}}$ & $0.05 \pm 0.01^{\mathrm{c}}$ & $0.12 \pm 0.01^{\mathrm{a}}$ & $0.06 \pm 0.01^{\mathrm{c}}$ \\
LDL-CH** & $58.3 \pm 18.3^{\mathrm{ab}}$ & $3.2 \pm 2.4^{\mathrm{c}}$ & $73.3 \pm 2.7^{\mathrm{a}}$ & $23.9 \pm 2.5^{\mathrm{b}}$ \\
HDL-CH** & $37.0 \pm 6.4^{\mathrm{a}}$ & $33.0 \pm 10.3^{\mathrm{a}}$ & $29.3 \pm 2.5^{\mathrm{a}}$ & $25.9 \pm 5.6^{\mathrm{a}}$ \\
VLDL-CH** & $8.4 \pm 5.8^{\mathrm{a}}$ & $15.0 \pm 3.7^{\mathrm{a}}$ & $15.6 \pm 6.1^{\mathrm{a}}$ & $15.5 \pm 0.5^{\mathrm{a}}$ \\
Glucose** & $139.8 \pm 32.0^{\mathrm{a}}$ & $189.9 \pm 32.3^{\mathrm{a}}$ & $178.7 \pm 49.1^{\mathrm{a}}$ & $163.7 \pm 38.3^{\mathrm{a}}$ \\
Insulin*** & $0.8 \pm 0.4^{\mathrm{a}}$ & $1.6 \pm 0.9^{\mathrm{a}}$ & $1.2 \pm 0.8^{\mathrm{a}}$ & $1.1 \pm 0.4^{\mathrm{a}}$ \\
TP\# & $7.3 \pm 0.8^{\mathrm{a}}$ & $7.0 \pm 1.1^{\mathrm{a}}$ & $7.1 \pm 0.8^{\mathrm{a}}$ & $6.6 \pm 1.2^{\mathrm{a}}$ \\
Albumin*** & $4.7 \pm 0.4^{\mathrm{a}}$ & $4.3 \pm 0.4^{\mathrm{b}}$ & $4.9 \pm 0.6^{\mathrm{a}}$ & $3.7 \pm 0.2^{\mathrm{c}}$ \\
\hline
\end{tabular}

TL - Total Lipid; TCH - Total Cholesterol, TG - Triacylglycerols, * $(\%)$;* $(\mathrm{mg} / \mathrm{dL})$; *** $(\mathrm{ng} / \mathrm{dL}) ; \#(\mathrm{~g} / \mathrm{dL})$. Values are expressed as mean $( \pm$ $\mathrm{SD})$ for six rats. Rows bearing the same letter showed no significant difference between means

Table 3. Cecum and fecal bile and fatty acid contents after consuming the diets for 48 days

\begin{tabular}{ccccc}
\hline Acid contents $(\mathrm{g} / 100 \mathrm{~g})$ & AIN 12 & AM 12 & AIN 18 & AM 18 \\
\hline Feces & & & & \\
Total Lipid & $3.3 \pm 0.15^{\mathrm{b}}$ & $7.4 \pm 0.36^{\mathrm{a}}$ & $3.2 \pm 0.40^{\mathrm{b}}$ & $7.9 \pm 0.38^{\mathrm{a}}$ \\
Cholic acid & $11.9 \pm 0.01^{\mathrm{a}}$ & $8.6 \pm 0.00^{\mathrm{b}}$ & $9.3 \pm 0.00^{\mathrm{b}}$ & $11.9 \pm 0.00^{\mathrm{c}}$ \\
Chenocholic acid & $29.8 \pm 0.01^{\mathrm{a}}$ & $31.4 \pm 0.01^{\mathrm{a}}$ & $30.7 \pm 0.05^{\mathrm{a}}$ & $35.0 \pm 0.03^{\mathrm{a}}$ \\
Lithocholic acid & $4.2 \pm 0.00^{\mathrm{bc}}$ & $3.8 \pm 0.00^{\mathrm{c}}$ & $8.1 \pm 0.01^{\mathrm{a}}$ & $6.5 \pm 0.01^{\mathrm{a}}$ \\
Deoxychenocholic acid & $7.0 \pm 0.01^{\mathrm{c}}$ & $10.5 \pm 0.00^{\mathrm{a}}$ & $7.4 \pm 0.01^{\mathrm{c}}$ & $7.8 \pm 0.00^{\mathrm{bc}}$ \\
Cecum & & & & \\
Cholic acid & $6.9 \pm 0.00^{\mathrm{a}}$ & $4.6 \pm 0.01^{\mathrm{a}}$ & $5.0 \pm 0.01^{\mathrm{a}}$ & $6.6 \pm 0.01^{\mathrm{a}}$ \\
Chenocholic acid & $7.7 \pm 0.00^{\mathrm{a}}$ & $6.3 \pm 0.03^{\mathrm{a}}$ & $5.6 \pm 0.01^{\mathrm{a}}$ & $8.0 \pm 0.02^{\mathrm{a}}$ \\
Lithocholic acid & $3.0 \pm 0.00^{\mathrm{a}}$ & $3.0 \pm 0.00^{\mathrm{a}}$ & $2.4 \pm 0.00^{\mathrm{a}}$ & $3.0 \pm 0.01^{\mathrm{a}}$ \\
Deoxychenocholic acid & $5.4 \pm 0.01^{\mathrm{a}}$ & $4.5 \pm 0.01^{\mathrm{a}}$ & $5.0 \pm 0.02^{\mathrm{a}}$ & $5.5 \pm 0.01^{\mathrm{a}}$ \\
Acetic acid & $0.44 \pm 0.08^{\mathrm{a}}$ & $0.51 \pm 0.03^{\mathrm{a}}$ & $0.43 \pm 0.10^{\mathrm{a}}$ & $0.45 \pm 0.06^{\mathrm{a}}$ \\
Propionic acid & $0.02 \pm 0.01^{\mathrm{a}}$ & $0.02 \pm 0.00^{\mathrm{a}}$ & $0.03 \pm 0.01^{\mathrm{a}}$ & $0.02 \pm 0.00^{\mathrm{a}}$ \\
Butyric acid & $0.12 \pm 0.03^{\mathrm{b}}$ & $0.57 \pm 0.01^{\mathrm{a}}$ & $0.21 \pm 0.04^{\mathrm{b}}$ & $0.75 \pm 0.08^{\mathrm{a}}$ \\
\hline
\end{tabular}

Values are expressed as mean $( \pm \mathrm{SD})$ for six rats. Rows bearing the same letter showed no significant difference between means 


\subsection{Fecal and Intestinal Parameters}

Although the amount of fecal lipids did not exhibit any alteration as a result of increasing the level of either of the dietary proteins, from 12 to $18 \%$, the substitution of casein for amaranth in the diet did produce an outstanding two-fold elevation of the total output of fecal lipids. Such an increase could be partly consistent with the five to six-fold increase in butyric acid noticed in the cecum contents against no alteration in the levels of either the acetic or propionic acids. It was remarkable, however, that the increase of butyric acid in the cecum appeared not to depend on the level of dietary protein (Table 3).

\section{Discussion}

Regarding the effect of the diet modification on the fecal bile acids, some differences were observed that were related to both the protein level and the type of protein. Excretion of the primary bile acid, cholic acid, was diminished in both the AIN-18 and AM-12 groups, compared to the other two diets, whereas no alteration was found in the contents of the other primary acid, chenodeoxycholic acid. Meanwhile, the level of the dietary protein had a clear influence on the secondary acids of the amaranth group, indicating that excretion of lythocholic acid increased by about $100 \%$ as the protein content was raised by $50 \%$. Excretion of the undesirable deoxycholic acid, in turn, increased commensurably with the decrease of its precursor, cholic acid, as casein was partially substituted for by the amaranth protein (Table 3).

Various studies have reported cholesterol-lowering effects of several of the main fractions of amaranth using hypercholesterolemic experimental animals[6-11] in reducing total serum cholesterol.

Hypercholesterolemic rats fed hypercholesterolemic diets for 28 days containing amaranth showed significant decreases of serum total cholesterol and triacylglycerol levels[10]. In the light of our results, however, it is suggested that the same determinant factors or mechanism responsible for the cholesterol-lowering effect in the hypercholesterolemic were also operating in the normocholesterolemic animal yet, without diminishing the HDL-cholesterol levels as has been found in the hypercholesterolemic studies. Likewise, reduction in the levels of serum cholesterol has been observed in chickens[6], hamsters[8] and rats that had their diets supplemented with the oil or squalene isolated from amaranth[7].

Different fractions of the grain, however, have shown varying effects. Hamsters fed a diet prepared with amaranth protein isolate, for instance, exhibited significant reduction in the serum levels of total cholesterol, but this decrease also included an undesirable reduction in HDL-cholesterol[13]. Alternatively, Berger et al. [8] have found that whereas the refined oil, crude oil or flakes do not show significant reductions of cholesterol in hypercholesterolemic hamsters, the intervention did diminish the levels of serum triacylglycerols in the refined oil group.
Meanwhile, another study conducted with protein-induced hypercholesterolemic rabbits, which later received a normolipidemic diet supplemented with either extruded or defatted amaranth, or the oil fraction, showed that substantial reductions of total and LDL-cholesterol did occur with the extruded flour than when the oil fraction was used[11]. In our study with normolipidemic, normocholesterolemic rats and diets, however, the reduction in LDL-cholesterol was substantial even with only $35 \%$ substitution of the protein. This was most noteworthy because knowing that $50 \%$ of the cholesterol is transported by the HDL particles[26], no accompanying reduction of the HDL-cholesterol occurred. These results therefore suggest that routine consumption of a diet with partial substitution of dietary protein by extruded amaranth grain can exert a cholesterol lowering effect without bringing a negative impact on the levels of HDL-cholesterol in normocholesterolemic individuals.

Although the amaranth grain has a nutrient composition that makes it potentially hypercholesterolemic, it is still possible that the simple substitution of $35 \%$ of the casein with the vegetable protein was partly responsible for the observed effect. Carrol and Kurowska[27] have shown that the mere substitution of casein with another protein, like that of soy, can have an LDL-cholesterol reducing effect in rabbits and rats. Since the extruded amaranth has a methionine/lysine ratio similar to that of soy protein[11], the possibility that this factor be also partly responsible for the overall serum cholesterol reduction of amaranth cannot be excluded. However, the additional effects noticed on the fatty and bile acid profiles could not be attributed to the partial substitution of casein.

A greater excretion of fecal lipids was also observed in the group of animals fed the extruded amaranth flour (Table 3), an effect that could be attributed to either the presence of fiber, antioxidant substances, or specific proteins, or even to a combination of two or three of these[9]. This effect has been also observed in mice fed a diet supplemented with quinoa protein and the hypocholesterolemic effect suggesting that the decrease in cholesterol level was associated to both inhibition of synthesis and stimulation of catabolism of cholesterol as well as the inhibition of the re-absorption of bile acids from the intestine [28]. It should be noted that this effect did not influence the normal serum triacylglycerol levels.

Dietary fibers have long been recognized as having such physiological properties as a lowering effect of both serum sugar and cholesterol levels[29]. Their intestinal fermentation may give rise to short-chain fatty acids thus favoring a lower intestinal $\mathrm{pH}$, which is associated with a lesser population of pathogenic colonic microbiota, lower solubility of bile acids and an increased absorbability of minerals and a reduction of ammonia absorption from the intestine[30]. The lower colonic $\mathrm{pH}$ could also inhibit the enzyme $7 \alpha$-dehydroxylase, which is responsible for the conversion of primary into secondary bile acids[31]. Among the short-chain fatty acids, the advantages of butyric acid stand out because of its ability to help regulate the process of 
cell differentiation and to stimulate the immunogenicity of cancerous cells[30-32]. In our study a greater production of butyric acid was found in the groups of animals that received the amaranth diets (Table 3). Inclusion of the amaranth flour in the diets also increased the proportion of dietary fiber and, particularly soluble fibers, which were not present in the control diet. A direct impact on fermentation and short-chain fatty acid generation, mainly butyrate, has been reported to occur from the substitution of the standard cellulose fiber by natural sources of fiber[33-34].

Normally, about $5 \%$ of the bile acid pool is removed daily from the entero-hepatic circulation by way of fecal excretion[35]. Considering that cholesterol is a precursor of the primary bile acids, such loss should then represent a net decrease in circulating cholesterol. It appears therefore that the ability of amaranth to promote a higher excretion of both deoxycholic acid and total lipids may be at least partly responsible for the cholesterol lowering effect of this grain. It has also been shown that amaranth, as is the case with quínoa, exhibits in vitro bile-acid binding capacity, especially of the secondary bile acids[28,36]. It should be pointed out, however, that a similar effect has been reported in rats fed diets containing resistant starch from two different bean cultivars[37].

Although one study has reported that extruded amaranth can have a high glycemic index in vitro[38], our serum glucose and insulin data showed no detectable adverse response of the rat in the present study.

\section{Conclusions}

From the above data it is concluded that chronic consumption of supplementary amounts of extruded amaranth grain by normolipidemic young Wistar rats promoted the decrease of serum total and LDL-cholesterol without affecting the HDL-cholesterol fraction, different from what has been observed in studies with hypercholesterolemic animals. It was also evident that the levels of either serum glucose or insulin were significantly affected by the long term supplementation. Moreover, inclusion of the extruded amaranth in the diet promoted higher excretions of total lipids and of the undesirable secondary bile acid, deoxycholic acid; the latter observation being consistent with the cholesterol-lowering effect observed in the plasma. Finally, no reduction of circulating triacylglycerols below normal levels was detected after chronic consumption of this grain by the normolipidemic rat.

Our data support the notion that moderate routine consumption of whole, extruded amaranth does not cause any visible metabolic imbalance and that it is not necessary to substitute the entire dietary protein in order for the normal rat to obtain its potential health benefits. Considering the impact that the more common farinaceous or proteinaceous components of the classical western diet has on human health, the present data obtained in young rats also suggest that further studies should be pursued in young humans. The possibility that judicious or moderate substitution of classical staples for amaranth products in the diet of the young population should redound favorably in better public health is not negligible.

\section{ACKNOWLEDGEMENTS}

The authors acknowledge the kind cooperation of Dr. Carlos Roberto Spehar, of Empresa Brasileira de Pesquisa Agropecuária (EMBRAPA) - Cerrados, for the donation of the amaranth grain, and to the Brazilian National Council for Cientific and Technological Development - CNPq for grants 302901/2005 and 134179-2007-2. Thanks are also due to Mrs. Onéida Vasconcelos and to CBO Analítica, Campinas, $\mathrm{SP}$, for the fatty and bile acid determinations.

\section{REFERENCES}

[1] Caselato-Sousa, V.M. and J. Amaya-Farfán, State of Knowledge on Amaranth Grain: A Comprehensive Review. Journal of Food Science, 2012. 77(4): p. R93-R104.

[2] Guzman-Maldonado, S.H. and O. Paredes-Lopez, Functional products of plants indigenous to Latin America: amaranth, quinoa, common beans, and botanicals., in Functional Foods: Biochemical \& Processing Aspects., G. Mazza, Editor. 1998, Tehnomic Publishing Co: Pennsylvania.

[3] Amaya-Farfan, J., R. Marcilio, and C.R. Spehar, Deveria o Brasil investir em novos grãos para a sua alimentação? A proposta do amaranto (Amaranthus sp.). Segurança Alimentar e Nutricional, 2005. 12(1): p. 47-56.

[4] Menezes, E.W.L., F.M., Marcadores in vivo e in vitro para avaliação de carboidratos. Carbohidratos en Alimentos Regionales Iberoamericanos., ed. F.M.M. Lajolo, E.W. 2006, São Paulo: Editora da Universidade de São Paulo.

[5] Tosi, E.A., et al., Dietary fiber obtained from amaranth (Amaranthus cruentus) grain by differential milling. Food Chemistry, 2001. 73(4): p. 441-443.

[6] Qureshi, A.A., J.W. Lehmann, and D.M. Peterson, Amaranth and its oil inhibit cholesterol biosynthesis in 6-week-old female chickens. J Nutr, 1996. 126(8): p. 1972-8.

[7] Shin, D.H., et al., Amaranth squalene reduces serum and liver lipid levels in rat fed a cholesterol diet. British Journal of Biomedical Science, 2004. 61(1): p. 11-14.

[8] Berger, A., et al., Cholesterol-lowering properties of amaranth flakes, crude and refined oils in hamsters. Food Chemistry, 2003. 81(1): p. 119-124.

[9] Czerwinski, J., et al., Oat (Avena sativa L.) and amaranth (Amaranthus hypochondriacus) meals positively affect plasma lipid profile in rats fed cholesterol-containing diets. J Nutr Biochem, 2004. 15(10): p. 622-9.

[10] Grajeta, H., Effect of amaranth and oat bran on blood serum and liver lipids in rats depending on the kind of dietary fats. Nahrung, 1999. 43(2): p. 114-7.

[11] Plate, A.Y.A. and J.A.G. Areas, Cholesterol-lowering effect of extruded amaranth (Amaranthus caudatus L.) in 
hypercholesterolemic rabbits. Food Chemistry, 2002. 76(1): p. $1-6$.

[12] Chaturvedi, A., G. Sarojini, and N.L. Devi, Hypocholesterolemic effect of amaranth seeds (Amaranthus esculantus). Plant Foods Hum Nutr, 1993. 44(1): p. 63-70.

[13] Mendonca, S., et al., Amaranth protein presents cholesterol-lowering effect. Food Chemistry, 2009. 116(3): p. 738-742.

[14] Berger, A., et al., Cholesterol-lowering properties of amaranth grain and oil in hamsters. International Journal for Vitamin and Nutrition Research, 2003. 73(1): p. 39-47.

[15] Reeves, P.G., F.H. Nielsen, and G.C. Fahey, Ain-93 Purified Diets for Laboratory Rodents - Final Report of the American Institute of Nutrition Ad Hoc Writing Committee on the Reformulation of the Ain-76a Rodent Diet. Journal of Nutrition, 1993. 123(11): p. 1939-1951.

[16] Fossati, P. and L. Prencipe, Serum Triglycerides Determined Colorimetrically with an Enzyme That Produces Hydrogen-Peroxide. Clinical Chemistry, 1982. 28(10): p. 2077-2080.

[17] Mcgowan, M.W., et al., A Peroxidase-Coupled Method for the Colorimetric Determination of Serum Triglycerides. Clinical Chemistry, 1983. 29(3): p. 538-542.

[18] Anandaraja, S., et al., Low-density lipoprotein cholesterol estimation by a new formula in Indian population. Int $\mathbf{J}$ Cardiol, 2005. 102(1): p. 117-20.

[19] Scott, A.M., I. Atwater, and E. Rojas, A Method for the Simultaneous Measurement of Insulin Release and B-Cell Membrane-Potential in Single-Mouse Islets of Langerhans. Diabetologia, 1981. 21(5): p. 470-475.

[20] Bragagnolo, N. and D. Rodriguez-Amaya, Otimização da determinação de colesterol por clae e teores de colesterol, lipídios totais e ácidos graxos em camarão rosa (Penaeus brasiliensis). Ciência e Tecnologia de Alimentos, 1997. 17: p. 275-280.

[21] Guerrant, G.O., M.A. Lambert, and C.W. Moss, Analysis of Short-Chain Acids from Anaerobic-Bacteria by High-Performance Liquid-Chromatography. Journal of Clinical Microbiology, 1982. 16(2): p. 355-360.

[22] Canale, A., M.E. Valente, and A. Ciotti, Determination of Volatile Carboxylic-Acids (C1-C5i) and Lactic-Acid in Aqueous Acid-Extracts of Silage by High-Performance Liquid-Chromatography. Journal of the Science of Food and Agriculture, 1984. 35(11): p. 1178-1182.

[23] Batta, A.K. and G. Salen, Gas chromatography of bile acids. Journal of Chromatography B-Analytical Technologies in the Biomedical and Life Sciences, 1999. 723(1-2): p. 1-16.

[24] Batta, A.K., et al., Capillary gas-liquid chromatography of acetate-methyl esters of bile acids. Journal of Chromatography A, 1997. 766(1-2): p. 286-291.
[25] Batta, A.K., et al., Highly simplified method for gas-liquid chromatographic quantitation of bile acids and sterols in human stool. Journal of Lipid Research, 1999. 40(6): p. $1148-1154$.

[26] Brattsand, R., Distribution of cholesterol and triglycerides among lipoprotein fractions in fat-fed rabbits at different levels of serum cholesterol. Atherosclerosis, 1976. 23(1): p. 97-110.

[27] Carroll, K.K. and E.M. Kurowska, Soy Consumption and Cholesterol Reduction - Review of Animal and Human Studies. Journal of Nutrition, 1995. 125(3): p. S594-S597.

[28] Takao, T., et al., Hypocholesterolemic effect of protein isolated from quinoa (Chenopodium quinoa Willd.) seeds. Food Science and Technology Research, 2005. 11(2): p. 161-167.

[29] Bagchi, K., T. Datta, and R. Ray, Influence of Dietary Protein and Methionine on Serum Cholesterol Level. American Journal of Clinical Nutrition, 1963. 13(4): p. 232-\&.

[30] Morita, T., et al., Cholesterol-lowering effects of soybean, potato and rice proteins depend on their low methionine contents in rats fed a cholesterol-free purified diet. Journal of Nutrition, 1997. 127(3): p. 470-477.

[31] Drzikova, B., et al., The composition of dietary fibre-rich extrudates from oat affects bile acid binding and fermentation in vitro. Food Chemistry, 2005. 90(1-2): p. 181-192.

[32] Wong, J.M.W., et al., Colonic health: Fermentation and short chain fatty acids. Journal of Clinical Gastroenterology, 2006. 40(3): p. 235-243.

[33] Maathuis, A., et al., The Effect of the Undigested Fraction of Maize Products on the Activity and Composition of the Microbiota Determined in a Dynamic in Vitro Model of the Human Proximal Large Intestine. Journal of the American College of Nutrition, 2009. 28(6): p. 657-666.

[34] Hermes, R.G., et al., Effect of dietary level of protein and fiber on the productive performance and health status of piglets. Journal of Animal Science, 2009. 87(11): p. 3569-3577.

[35] Nugent, A.P., Health properties of resistant starch. British Nutrition Foundation Nutrition Bulletin, 2005. 30(1): p. $27-54$.

[36] Tiengo, A., E.M. Motta, and F.M. Netto, Chemical composition and bile acid binding activity of products obtained from amaranth (Amaranthus cruentus) seeds. Plant Foods Hum Nutr, 2011. 66(4): p. 370-5.

[37] Han, K.H., et al., Enzyme-resistant fractions of beans lowered serum cholesterol and increased sterol excretions and hepatic mRNA levels in rats. Lipids, 2003. 38(9): p. 919-24.

[38] Capriles, V.D., et al., Effects of processing methods on amaranth starch digestibility and predicted glycemic index. Journal of Food Science, 2008. 73(7): p. H160-H164. 